\title{
Struktur Populasi Ikan Seluang (Rasbora argyrotaenia) di Hilir Sungai Sekadau Kecamatan Sekadau Hilir Kabupaten Sekadau
}

\author{
Fransiska Yeni Suryani ${ }^{1}$, Tri Rima Setyawati ${ }^{1}$, Ari Hepi Yanti $^{1}$ \\ ${ }^{1}$ Program Studi Biologi, Fakultas MIPA, Universitas Tanjungpura, JL. Prof. Dr. H. Hadari Nawawi, Pontianak \\ Email korespondensi: suryafrans47@gmail.com
}

\begin{abstract}
Rasbora argyrotaenia is one of the species of freshwater fish that found in downstream at the Sekadau river. The seluang fish population ( $R$. argyrotaenia) river downstream is in danger of declining as a result of public activity. The goal of the study is to identify the structure of $R$. argyrotaenia population and the chemical factors of the water downstream from the Sekadau River. Data extraction takes place between March and April 2018. Fish are found three times in three weeks at a week's interval of 1 week at a time. Studies show that seluang fish ( $R$. argyrotaenia) were found up to 213 individuals of 69 individuals females, 58 individual males and 86 individual unidentified. The seluang fish that is most commonly found $2-6 \mathrm{~cm}$ by 131 individuals, and the smallest one at $12-16 \mathrm{~cm}$ size is 4 individuals. The gender ratio of male and female fish to the four stations is $1: 1$.
\end{abstract}

Key words: Rasbora argyrotaenia, population structure, genitalia ratio, the Sekadau river

\section{PENDAHULUAN}

Rasbora merupakan salah satu genus ikan air tawar dari Famili Cyprinidae. Diperkirakan terdapat 143 spesies ikan di dunia yang berasal dari famili Cyprinidae (Fish Base, 2012), dan 45 spesies diantaranya terdapat di Indonesia (Kottelat et al., 1993). Di Indonesia, Rasbora banyak ditemukan di Sumatera, Kalimantan dan Jawa. Ikan tersebut merupakan ikan konsumsi yang penting di Indonesia dan dapat juga dimanfaatkan sebagai ikan hias (Said \& Mayasari, 2010).

Salah satu jenis ikan Rasbora adalah Rasbora argyrotaenia yang hidup di perairan tawar di Pulau Kalimantan dengan dasar perairan berupa pasir dan batuan kecil. Ikan seluang banyak ditemukan pada daerah hulu dan tengah sungai. Ikan tersebut sangat jarang ditemukan pada daerah berlumpur seperti pada daerah hilir dan muara, hidup di sungai pada kedalaman kurang dari 1 meter (Ahmad \& Nofrizal, 2011).

Sungai Sekadau adalah salah satu sungai yang berada di Kalimantan Barat tepatnya di Kabupaten Sekadau. Sungai ini merupakan sungai terpanjang di Kabupaten Sekadau dengan panjang $\pm 117 \mathrm{Km}$ dan lebar 80-150 meter (BPS, 2011). Air Sungai Sekadau mengalir melewati Kecamatan Nanga Mahap, Kecamatan Nanga Taman, Kecamatan Sekadau Hulu, Kecamatan Sekadau Hilir dan bermuara di Sungai Kapuas. Ikan yang cukup banyak di Sungai Sekadau dimanfaatkan masyarakat sekitar untuk dikonsumsi dengan cara memancing dan menjaring.
Aktivitas yang dilakukan masyarakat di bagian Hulu Sungai Sekadau, seperti penambangan pasir, pembukaan lahan untuk pemukiman penduduk perkebunan sawit, dan aktivitas penyeberangan kapal motor dapat memengaruhi keseimbangan ekosistem sungai. Apabila hal tersebut dilakukan secara terus-menerus akan berdampak negatif terhadap kualitas air sungai dan mengakibatkan rusaknya ekosistem sungai di sekitarnya. Rusaknya ekosistem sungai berdampak pula pada populasi ikan yang berkurang, baik secara kualitas maupun kuantitas. Tujuan dari penelitian ini mengetahui struktur populasi ikan seluang ( $R$. argyrotaenia) dan hubungan faktor fisik-kimiawi perairan dengan kepadatan ikan seluang ( $R$. argyrotaenia) di hilir Sungai Sekadau.

\section{BAHAN DAN METODE}

\section{Waktu dan Tempat Penelitian}

Penelitian dilaksanakan selama 3 bulan, mulai dari bulan Maret hingga Mei 2018. Penelitian ini dilakukan di Hilir Sungai Sekadau, Kecamatan Sekadau Hilir, Kabupaten Sekadau, Kalimantan Barat dan di Laboratorium Zoologi Fakultas Matematika dan Ilmu Pengetahuan Alam Universitas Tanjungpura Pontianak.

\section{Deskripsi Lokasi}

Sungai Sekadau merupakan sungai terpanjang di Kabupaten Sekadau yang melintasi 4 kecamatan yaitu Kecamatan Nanga Mahap, Nanga Taman, Sekadau Hulu dan bermuara di Sungai Kapuas di 
Kecamatan Sekadau Hilir. Sungai Sekadau mempunyai vegetasi dan rona lingkungan yang bervariasi. Substrat dasar berupa pasir dan bebatuan.

\section{Alat dan Bahan}

Alat - alat yang digunakan dalam penelitian ini adalah adalah jaring insang (gill net) ukuran 2 inchi, posat (jaring angkat tradisional), coolbox, GPS GARMIN Etrex 30, kamera, gunting, spidol permanen, plastik packing, number tagging, jangka sorong, mistar, pinset, serokan, ember, termometer, sechi disk, stopwatch, bola pimpong, $\mathrm{pH}$ meter, kertas label, botol film, botol Winkler. Bahan-bahan yang digunakan dalam penelitian ini adalah alkohol $70 \%$, akuades, formalin $10 \%$, $(\mathrm{KOH}-\mathrm{KI}),\left(\mathrm{MnSO}_{4}\right)$, $\left(\mathrm{H}_{2} \mathrm{SO}_{4}\right)$ pekat, indikator amilum $0,5 \%$, indikator fenolftalein (PP), $\left(\mathrm{Na}_{2} \mathrm{CO}_{3}\right) 0,01 \mathrm{~N}$ dan natrium $\left(\mathrm{Na}_{2} \mathrm{SO}_{3}\right) 0,023 \mathrm{~N}$.

\section{Metode Penelitian}

Stasiun penelitian ditentukan berdasarkan perbedaan rona lingkungan yang ada di Sungai Sekadau. Berdasarkan hasil survei awal ditetapkan 4 stasiun yang dapat dilihat pada Gambar 1 dan Tabel 1.



Gambar 1. Peta Stasiun Penelitian Berdasarkan Mapsource 2018

Tabel 1. Lokasi Habitat Stasiun Penelitian

\begin{tabular}{|c|c|c|}
\hline Stasiun & Titik Koordinat & Vegetasi dan Rona Lingkungan \\
\hline $\mathrm{I}$ & $\begin{array}{l}00^{\circ} 01^{\prime} 30.4 " \text { ' LU } \\
110^{\circ} 533^{\prime} 33.9 \text { 'LS }\end{array}$ & $\begin{array}{l}\text { Berada paling dekat dengan pertemuan arus Sungai Sekadau dan } \\
\text { Sungai Kapuas dengan substrat berupa pasir berlumpur dan terdapat } \\
\text { pemukiman penduduk di kanan dan kiri Sungai. }\end{array}$ \\
\hline 2 & $\begin{array}{l}00^{\circ} 01^{\prime} 21.4 ” \mathrm{LU} \\
110^{\circ} 53^{\prime} 43.7^{\prime} \mathrm{LS}\end{array}$ & $\begin{array}{l}\text { Berada di dekat anak sungai, substrat dasarnya berupa pasir dan } \\
\text { sedikit berlumpur dengan aliran air yang tenang dengan pepohonan } \\
\text { durian dan perkebunan karet dipinggiran sungai. }\end{array}$ \\
\hline 3 & $\begin{array}{l}00^{\circ} 01^{\prime} 07.1 \text { ” LU } \\
110^{\circ} 54^{\prime} 32.3 \text { 'LS }\end{array}$ & $\begin{array}{l}\text { Berada di dekat area pertambangan pasir dengan substrat dasar berupa } \\
\text { pasir. }\end{array}$ \\
\hline 4 & $\begin{array}{l}01^{\circ} 01^{\prime} 30.8 ” \text { LU } \\
110^{\circ} 54^{\prime} 31.8 ’ \mathrm{LS}\end{array}$ & $\begin{array}{l}\text { Berada di dekat Jembatan Penanjung dengan substrat berupa bebatuan } \\
\text { dan di temukan beberapa lanting diatas sungai. }\end{array}$ \\
\hline
\end{tabular}


Pengambilan sampel ikan dilakukan sebanyak 3 kali selama 3 minggu yakni dengan interval waktu 1 minggu 1 kali. Ikan ditangkap dengan menggunakan pukat berukuran panjang $20 \mathrm{~m}$ dan lebar $2 \mathrm{~m}$ dengan mata jaring $1 \mathrm{~cm}$ dan alat tangkap tradisional berupa Posat. Pukat dipasang mulai pukul 06.00 WIB dengan rentang waktu 15 menit pada setiap stasiun dan diangkat kembali setiap 4 jam agar ikan yang terperangkap tidak mati, sehingga total pengambilan sampel ikan ialah sebanyak 3 kali selama satu hari. Posat dipasang pada saat pagi hari dengan cara ditenggelamkan dan diangkat secara terus menerus. Ikan hasil tangkapan yang diperoleh dicuci dengan air bersih kemudian dilakukan pengambilan gambar. Ikan yang telah difoto kemudian dianestasi dan diawetan dengan larutan formalin $10 \%$. Sampel yang sudah disuntik dimasukan ke dalam wadah tertutup yang berisi formalin $10 \%$. Sampel ikan kemudian dipindahkan ke dalam toples berisi larutan alkohol 70\% setelah 1 minggu (Roberts 1989; Kottelat et al.,1993).

Pengukuran kondisi fisika dan kimia perairan meliputi kedalaman, kecerahan, suhu, $\mathrm{pH}$, kecepatan arus, $\mathrm{CO} 2$, dan DO dilakukan sebanyak tiga kali yaitu pada waktu pagi, siang, serta sore hari dan diulang selama 3 hari.

\section{HASIL DAN PEMBAHASAN \\ Hasil}

Jumlah ikan seluang ( $R$. argyrotaenia) yang ditemukan dalam penelitian ini sebanyak 213 individu yang terdiri atas 69 individu ikan betina, 58 individu ikan jantan dan 86 individu ikan yang tidak teridentifikasi jenis kelaminnya. Perbedaan morfologi ikan seluang ( $R$. argyrotaenia) jantan betina dapat dilihat pada Tabel 2 .

Karakter morfologi individu ikan seluang ( $R$. argyrotaenia) dapat dibedakan berdasarkan jenis kelamin. Individu jantan memiliki karakter dengan panjang total berkisar 5,3-11,3 cm dan memiliki berat kisaran 1,40 - 12,77 g, memiliki bentuk tubuh pipih memanjang, ekor dan tubuh berwarna kuning cerah namun memiliki warna sirip dada kuning pudar, kepala berbentuk superior serta ukuran sisik kecil. Individu betina memiliki panjang total berkisar 4-13 cm dan kisaran berat 1,39-14,78 g, bentuk tubuh pipih membulat, warna ekor dan sirip dada kuning cerah, warna tubuh kuning pudar, memiliki bentuk kepala superior serta ukuran sisik yang lebih besar (Gambar 2).

$\underline{\text { Tabel 2. Perbedaan morfologi ikan seluang (R. argyrotaenia) jantan (§) dan betina (ㅇ) di hilir Sungai Sekadau }}$

\begin{tabular}{lccc}
\hline \multirow{2}{*}{ Karakter individu } & \multicolumn{3}{c}{ Jenis kelamin } \\
\cline { 2 - 4 } & $\hat{\jmath}(\mathrm{n}=58)$ & $\uparrow(\mathrm{n}=69)$ & $\begin{array}{c}\text { Tidak teridentifikasi } \\
(\mathrm{n}=86)\end{array}$ \\
\hline Panjang total $(\mathrm{cm})$ & $5,3-11,3$ & $4-13$ & $2-3,8$ \\
Berat $(\mathrm{g})$ & $1,40-12,77$ & $1,39-14,78$ & $0,4-1,26$ \\
Bentuk tubuh & Pipih memanjang & Pipih membulat & Pipih \\
Warna ekor & Kuning terang & Kuning pudar & Kuning \\
Sirip dada & Kuning terang & Kuning pudar & Kuning \\
Warna tubuh & Kuning terang & Kuning pudar & Kuning \\
Bentuk kepala & Superior & Superior & Superior \\
Sisik & Kecil & Besar & Kecil \\
\hline
\end{tabular}

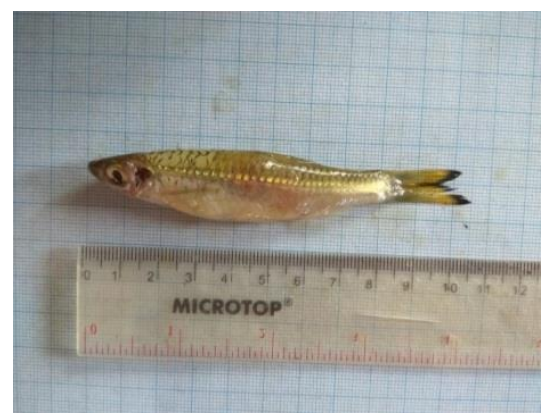

a

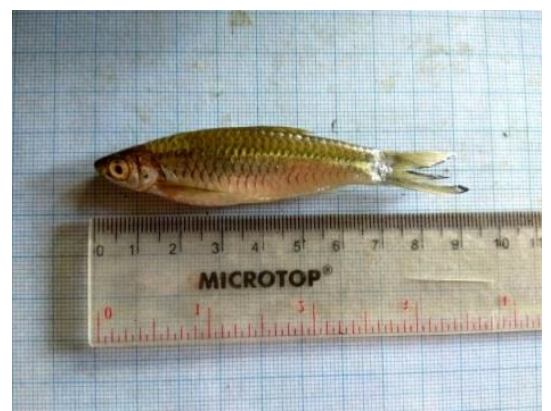

b

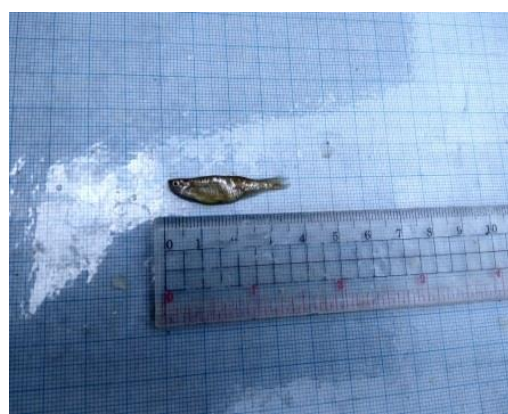

C

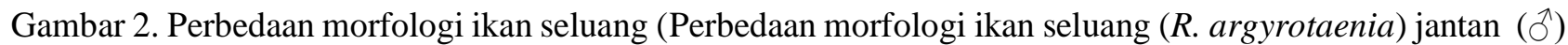
dan betina (+) di hilir Sungai Sekadau. (a) R. argyrotaenia jantan, (b) $R$. argyrotaenia betina, (c) $R$. argyrotaenia yang tidak teridentifikasi. 
Tabel 3. Kepadatan, Kepadatan Relatif dan Rasio Kelamin Ikan Seluang (R. argyrotaenia) di Hilir Sungai Sekadau

\begin{tabular}{|c|c|c|c|c|}
\hline Stasiun & $\begin{array}{l}\text { Jumlah total } \\
\text { indvidu (n) }\end{array}$ & $\begin{array}{c}\text { Jumlah individu } \\
\text { teridentifikasi } \\
(\hat{0}:+)\end{array}$ & $\begin{array}{l}\text { Jumlah individu } \\
\text { tidak teridentifikasi }\end{array}$ & $\begin{array}{c}\text { Rasio kelamin } \\
\left(\delta^{\lambda}:+\right)\end{array}$ \\
\hline I & 47 & $13: 15$ & 19 & $1: 1$ \\
\hline II & 60 & $17: 23$ & 20 & $1: 1$ \\
\hline III & 46 & $13: 7$ & 26 & $1: 1$ \\
\hline IV & 60 & $15: 24$ & 21 & $1: 1$ \\
\hline
\end{tabular}

Jumlah ikan seluang yang tertangkap bervariasi pada tiap stasiun penelitian. Nisbah kelamin ikan

seluang (R. argyrotaenia) jantan dan betina selama penelitian memiliki rasio 1:1 (Tabel 3).

Pola pertumbuhan ikan seluang ( $R$. argyrotaenia) pada empat stasiun didapatkan pola allometrik positif dengan nilai $\mathrm{b}$ sebesar 3,04, yaitu pertambahan berat lebih cepat dibandingkan dengan pertambahan panjang (Gambar 3). Hasil analisis regresi diperoleh nilai $\mathrm{R}^{2}=0.8625$. Hal ini menunjukkan bahwa hubungan tersebut positif, dilihat dari garis regresi yang bergerak dari kiri bawah ke kanan atas (naik) (Gambar 3).

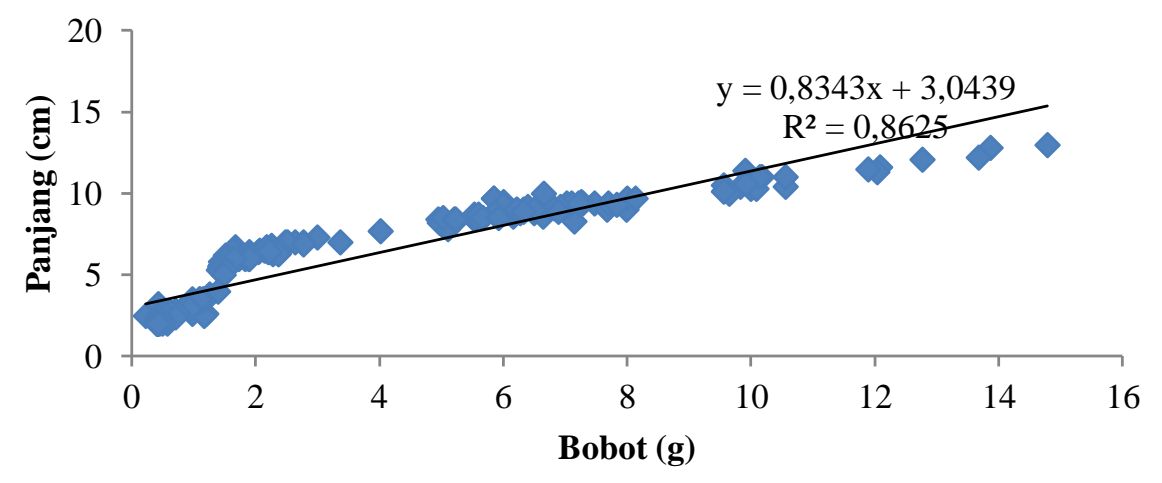

Gambar 3. Hasil analisis hubungan panjang-bobot ikan seluang ( $R$. argyrotaenia)

Frekuensi panjang ikan yang terbanyak ditemukan pada ikan berukuran $2-6 \mathrm{~cm}$ sebanyak 131 individu yang termasuk ke dalam kategori ikan seluang muda. Ikan seluang berukuran sedang dengan kisaran panjang $7-11 \mathrm{~cm}$ ditemukan sebanyak 78 individu, sedangkan ikan seluang berukuran dewasa dengan kisaran $12-16 \mathrm{~cm}$ ditemukan paling sedikit berjumlah 4 individu (Gambar 4).

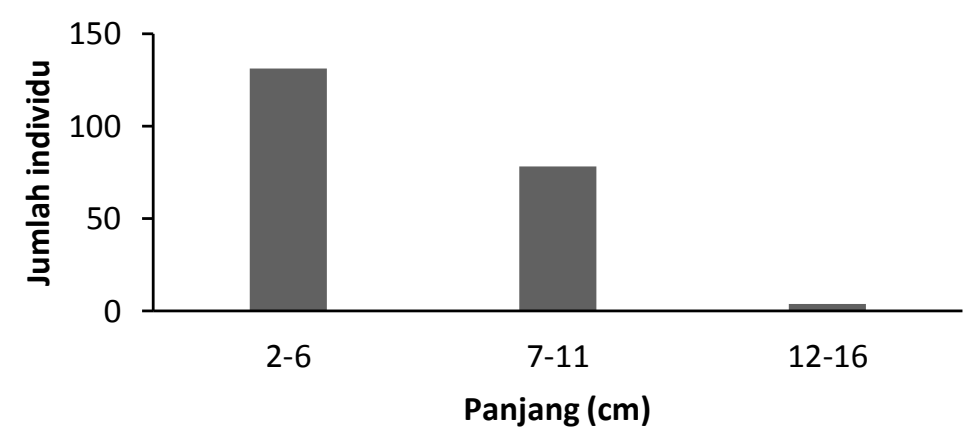

Gambar 4. Distribusi frekuensi panjang ikan seluang (R. argyrotaenia) di hilir Sungai Sekadau 
Jumlah individu ikan seluang jantan dan betina yang ditemukan pada distribusi frekuensi panjang ikan memiliki jumlah yang berbeda, sebanyak 21 individu jantan dan 24 individu betina yang ditemukan pada ikan seluang dengan ukuran 4-6 cm. Ikan seluang berukuran 7-11 cm ditemukan sebanyak 32 individu jantan dan 42 individu betina, sedangkan ikan seluang dengan ukuran $12-16 \mathrm{~cm}$ terdapat 1 individu jantan dan 3 individu betina (Gambar 5).

$\begin{array}{lllllllllll}50 & 40 & 30 & 20 & 10 & 0 & 10 & 20 & 30 & 40 & 50\end{array}$

Gambar 5. Distribusi ukuran ikan seluang (R. argyrotaenia) jantan (III) dan betina (N) di hilir Sungai Sekadau

Hasil pengamatan parameter lingkungan di Hilir Sungai Sekadau disajikan pada Tabel 4. Parameter lingkungan tersebut antara lain suhu, $\mathrm{pH}$, kecerahan, kedalaman, kecepatan arus, Oksigen terlarut dan Karbondioksida.

Tabel 4. Hasil pengukuran faktor Fisika Kimia Air di Hilir Sungai Sekadau

\begin{tabular}{lcccc}
\hline \multirow{2}{*}{ Parameter air } & \multicolumn{3}{c}{ Stasiun } \\
\cline { 2 - 5 } & 1 & 2 & 3 & 4 \\
\hline Suhu $\left({ }^{0} \mathrm{C}\right)$ & 28 & 27,6 & 28 & 28 \\
pH & 5,50 & 5,63 & 5,54 & 5,43 \\
Kecerahan $(\mathrm{cm})$ & 89,1 & 63,8 & 91,8 & 72,8 \\
Kedalaman (m) & 4,20 & 3,40 & 3,85 & 2,23 \\
Kecepatan Arus (m/det) & 0,11 & 0,09 & 0,11 & 0,11 \\
Oksigen terlarut (mg/L) & 5,72 & 6,12 & 4,98 & 5,62 \\
Karbondioksida (mg/L) & 2,33 & 2,53 & 2,14 & 2,37 \\
\hline
\end{tabular}

\section{Pembahasan}

Ikan seluang $(R$. argyrotaenia $)$ yang diperoleh selama penelitian berjumlah 213 individu yang terdiri atas 69 individu ikan betina, 58 individu ikan jantan, dan 86 individu ikan yang tidak teridentifikasi jenis kelaminnya. Ikan yang tidak teridentifikasi jenis kelaminnya disebabkan oleh ukuran dari ikan tersebut terlalu kecil dengan kisaran panjang 2-3,8 cm sehingga tidak bisa untuk diidentifikasi. Rasio jenis kelamin ikan seluang dari setiap stasiun sama yaitu 1:1 (Tabel 3). Hasil analisis perbandingan jenis kelamin ikan tersebut menunjukkan bahwa tidak terdapat perbedaan jumlah ikan jantan dan betina pada setiap stasiun. Ball dan Rao (1984) menyatakan bahwa pada perairan normal diperkirakan memiliki perbandingan ikan jantan dan betina berkisar 1:1.

Populasi $R$. argyrotaenia memiliki frekuensi panjang tubuh yang berbeda. Frekuensi panjang tubuh menggambarkan kelompok umur populasi ikan. Ikan dengan kelompok umur yang sama tergambar dari puncak grafik distribusi panjang total (Gambar 4). Ikan seluang ( $R$. argyrotaenia) hasil tangkapan di hilir Sungai Sekadau memiliki panjang tubuh berkisar antara $2-16 \mathrm{~cm}$. Grafik distribusi panjang tubuh ikan menggambarkan kelompok umur ekologis, yaitu kecil, sedang dan besar. Kelompok ikan seluang kecil memiliki ukuran panjang 2-6 cm, ukuran sedang 7-11 cm, dan ukuran besar berkisar antara 12-16 cm (Gambar 4). 
Selama penelitian, diperoleh ikan $R$. argyrotaenia berukuran kecil sebanyak 131 individu, ikan berukuran sedang sebanyak 78 ekor, dan ikan berukuran besar sebanyak 4 individu (Gambar 4). Hal ini menunjukkan bahwa populasi ikan seluang yang ditemukan di hilir Sungai Sekadau selama penelitian didominansi oleh ikan-ikan berukuran kecil. Bentuk grafik ukuran juga menunjukkan bahwa populasi ikan seluang memiliki individu muda dalam jumlah besar. Hal ini serupa dengan pernyataan yang dikemukakan oleh Atetiningsih dan Windarti (2004) bahwa perkembangan gonad ikan $R$. trilineata yang ditangkap selama musim penghujan (di bulan Oktober - Desember) berada dalam keadaan pematangan gamet dan memijah atau melepaskan gamet. Penelitian ini dilakukan pada bulan Maret - April bukan merupakan musim memijah bagi ikan genus Rasbora yang mengakibatkan tidak adanya data mengenai kematangan gonad pada ikan $R$. argyrotaenia. Selain itu, kepadatan ikan dalam suatu habitat juga dipengaruhi oleh beberapa faktor antara lain kehadiran hewan lain (pemangsa dan pesaing), ketidakcocokan habitat, perilaku dan faktor fisikakimia lingkungan yang berbeda di luar kisaran toleransi ikan tersebut. Derajat Keasaman $(\mathrm{pH})$ merupakan salah satu faktor penentu kesuburan suatu perairan. Kondisi $\mathrm{pH}$ sangat memengaruhi kemampuan untuk tumbuh, bereproduksi dan kehidupan mikroorganisme dalam suatu pemeliharaan. Menurut Effendi (2003), kisaran optimum bagi ikan berkisar antara 5,5-7,8. Perairan hilir Sungai Sekadau memiliki nilai $\mathrm{pH}$ yang berkisar antara 5,43-5,63 (Tabel 4) sehingga masih mendukung untuk kehidupan ikan seluang.

Hubungan panjang-bobot ikan seluang diperoleh persamaan regresi yaitu $y=0,8343+3,043$ dengan koefisien determinasi $\mathrm{R}^{2}=0.8625$ (Gambar 3). Dari hasil tersebut diketahui nilai b $(3,043)$ untuk ikan seluang adalah sama dengan $3(b>3)$, sehingga dapat dinyatakan bahwa pertumbuhan alami ikan seluang allometrik yang artinya pertumbuhan bobot tubuh lebih cepat dari pada pertumbuhan panjang ikan. Untuk menentukan keeratan hubungan panjang berat ikan seluang, setelah dilakukan uji korelasi (R) dan diperoleh nilai $\mathrm{R}=0.8625$. Hasil ini menunjukkan bahwa hubungan tersebut positif, dilihat dari garis regresi yang bergerak dari kiri bawah ke kanan atas (naik). Hal ini disebabkan oleh melimpahnya makanan hasil deposit bahan biotik dan abiotik yang dibawa oleh arus sungai dari hulu ke bagian hilir sungai. Sungai di penelitian ini mampu mendukung ikan untuk mendapatkan makanan lebih banyak. Hal ini disebabkan karena lokasi penelitian ini berada di bagian hilir sungai atau di bagian muara sungai, sehingga banyak sumber makanan yang menumpuk. Penelitian ini mendapatkan hasil yang sama seperti yang dilakukan oleh Zakeyudin et al. (2012), bahwa hubungan panjang-bobot tubuh ikan seluang $(R$. sumatrana) di Aceh termasuk ke dalam allometrik positif dengan nilai $b=3,642$. Hal ini disebabkan meningkatnya makanan yang diperoleh oleh ikan yang terbawa arus air banjir dari bagian hulu ke hilir sungai.

Jumlah ikan seluang yang tertangkap bervariasi pada tiap stasiun penelitian (Tabel 3). Adanya perbedaan jumlah ikan yang tertangkap pada stasiun I, stasiun II, stasiun III dan stasiun IV diduga karena perbedaan kedalaman sungai, nilai kecerahan dan suhu. Kedalaman perairan di hilir Sungai Sekadau berkisar 2,23 - 4,20 m, sehingga masih dapat mendukung untuk pertumbuhan ikan. Menurut Hariyadi et al. (1992), kedalaman perairan yang baik dan normal untuk kehidupan organisme akuatik adalah 1,2-3 meter. Kedalaman akan memengaruhi kelimpahan hewan kecil dan juga memengaruhi penyebaran suhu dalam perairan. Hal ini menyebabkan jumlah ikan yang tertangkap di stasiun II dan IV lebih banyak. Ini sesuai dengan pernyataan Welcomme (2001), bahwa tinggi rendahnya permukan air sangat berpengaruh terhadap ikan dan organisme di dalam perairan, karena dapat memengaruhi perilaku ikan dan organisme air khususnya pada saat mencari makan.

Ikan seluang ( $R$. argyrotaenia) memiliki tingkat toleransi yang tinggi terhadap perubahan suhu sehingga masih dapat bertahan hidup pada suhu 20$30^{\circ} \mathrm{C}$ (Effendi, 2003). Nilai rata-rata suhu air selama penelitian memiliki kisaran nilai $27,6^{\circ} \mathrm{C}-28^{\circ} \mathrm{C}$ (Tabel 4). Dapat dikatakan bahwa suhu air di hilir Sungai Sekadau selama penelitian tidak mengalami perubahan, karena masih berkisar di angka $27^{\circ} \mathrm{C}$. Hal ini diduga akibat naungan dari pohon yang terdapat di sekitar stasiun penelitian, mengakibatkan intensitas cahaya matahari ke permukaan air menjadi berkurang. Perubahan suhu akan memengaruhi distribusi, metabolisme, nafsu makan, reproduksi organisme serta fotosintesis (Fujaya, 2004). Hal ini menyebabkan jumlah ikan yang tertangkap di stasiun I dan III lebih sedikit dengan kondisi stasiun yang lebih terbuka karena tidak terdapat pepohonan disekitarnya.

Penyebaran ikan di perairan dipengaruhi faktor kecerahan, oksigen terlarut dan karbondioksida bebas. Ikan dan organisme air lebih suka mencari 
makanan pada daerah yang mempunyi intensitas cahaya yang tinggi. Ikan lebih tertarik oleh cahaa pada keadaan lapar, sehingga ikan akan mencari makan ke arah tempat yang mempunai intensitas cahaya yang cukup tinggi (Sihombing, 2012). Kecerahan air di hilir Sungai Sekadau selama penelitian berkisar antara $63,8-91,8 \mathrm{~cm}$. Menurut Kordi (2010) kisaran kecerahan optimum bagi ikan diatas $0,3 \mathrm{~m}$. Kecerahan berpengaruh terhadap penyebaran ikan di perairan, metabolism serta produktivitas primer perairan (Fujaya, 2004). Hasil penelitian menunjukkan kecerahan tertinggi terdapat pada stasiun III yaitu $91,8 \mathrm{~cm}$ dan terendah di stasiun II yaitu 63,8 cm (Tabel 4). Menurut Baryan (2012), semakin rendah nilai kecerahan air suatu sungai akan menunjukan kualitas air yang rendah dan tidak subur, sebab sedimen yang terjadi juga besar. Kecerahan air di bawah $100 \mathrm{~cm}$ tergolong tingkat kecerahan rendah (Akromi dan Subroto, 2002). Permukaan air yang rendah menyebabkan banyaknya cahaya masuk ke dalam air, sedangkan permukaan air yang tinggi akan membuat cahaya sulit untuk menembus ke dasar perairan. Menurut Safitri (2015), intensitas cahaya memengaruhi pola tingkah laku makan, karena dapat memperluas jarak pakan dan memudahkan ikan dalam mencari atau memangsa makanannya. Menurut Hariyadi et al., (1992) faktor yang memengaruhi tingkat kecerahan perairan adalah cuaca matahari yang masuk kedalam perairan, keadaan cuaca, kekeruhan air, warna air dan waktu pengamatan sangat berpengaruh terhadap hasil pengukuran kecerahan.

Oksigen terlarut (Dissolved Oxygen) dibutuhkan oleh semua jasad hidup untuk pernapasan, proses metabolisme atau pertukaran zat yang kemudian menghasilkan energi untuk pertumbuhan dan pembiakan (Salmin, 2005). Oksigen terlarut merupakan variabel paling penting bagi pertumbuhan ikan seluang. Pada penelitian ini didapatkan kadar oksigen terlarut di hilir Sungai Sekadau dengan kisaran 4,98-6,12 mg/L (Tabel 4). Aktivitas penambangan pasir yang dilakukan pada stasiun III menyebabkan konsentrasi oksigen rendah. Kandungan oksigen terlarut di perairan hilir Sungai Sekadau rendah namun masih cukup baik untuk pertumbuhan organisme perairan. Muhtadi et al. (2017) menjelaskan bahwa kondisi perairan yang cocok untuk mendukung kehidupan ikan jumlah kandungan oksigen diatas $6 \mathrm{mg} / \mathrm{L}$. Kecepatan difusi oksigen dari udara, tergantung dari beberapa faktor, seperti kekeruhan air, suhu, salinitas dan pergerakan massa air (arus dan gelombang). Konsentrasi karbondioksida bebas di hilir Sungai Sekadau berkisar antara 2,14-2,53 mg/L (Tabel 4). Menurut
Asmawi (1983), kandungan karbondioksida dalam air tidak boleh lebih dari $12 \mathrm{mg} / \mathrm{L}$ dengan kadar terendah sebesar $2 \mathrm{mg} / \mathrm{L}$. Sehingga konsentrasi karbondioksida di hilir Sungai Sekadau masih dapat ditoleransi oleh ikan seluang ( $R$. argyrotaenia).

\section{DAFTAR PUSTAKA}

Ahmad, M, dan Nofrizal, 2011, Jurnal Perikanan dan Kelautan : Pemijahan dan Penjinakan Ikan Pantau (Rasbora latestriata), 16(1) : 71-78

Akromi dan Subroto 2002, Pengantar Limnologi, Gramedia, Jakarta

Atetiningsing, S, dan Windarti, 2004, Perkembangan Gonad Ikan Pantau (Rasbora trili-ineata) yang Ditangkap di Danau Lubuk Siam, Provinsi Riau, Ilmu Perairan Vol 2, No. 2, hal. 48 - 53

Asmawi, S, 1983, Pemeliharaan Ikan Dalam Keramba, Gramedia, Jakarta

Badan Pusat Statistik, 2011, Kabupaten Sekadau Dalam Angka Tahun 2011, Kalimantan Barat : Badan Pusat Statistik

Ball, D, V and K,V, Rao, 1984, Marine Fishes, Tata Mc Graw Hill Publishing Effort, FAO Fisheries Technical Paper, 243:39 $p$

Baryan, 2012, Kajian Kualitas Air Akibat Penambangan Emas di Danau Serantang Singkawang Selatan, Fakultas Pertanian, Universitas Tanjung Pura, Pontianak

Effendie, M,I, 2003, Biologi Perikanan, Yogyakarta: Yayasan Pustaka Nusantara

Fish Base, 2012, List of Nominal Species of Rasbora, [diakses tanggal 5 April2012], Tersedia Online Pada Laman, http://www,fishbase,org/summary/spesciesRas bora

Fujaya, 2004, Fisiologi Ikan Dasar Pengembangan Teknologi Perikanan, PT, Rineka Cipta, Jakarta

Haryadi, S, B, Widigdo dan I,N,N, Suryadiputra,1992, Limnologi, Metoda Analisa Kualitas Air, Fakultas Perikanan, Institut Pertanian Bogor, Bogor

Kordi, M, G, H, 2010, Panduan Lengkap Memelihara Ikan Air Tawar di Kolam Terpal, Lily publisher, Yogyakarta 
Kottelat, M, Whitten AJ, Kartikasari SN dan Wiroatmodjo S, 1993, Freshwater Fishes of Western Indonesia and Sulawesi, Edisi Dwi Bahasa Inggris-Indonesia, Periplus Edition (HK) Ltd, Bekerjasama dengan Kantor Menteri KLH, Jakarta, Indonesia

Muhtadi, A, O,R, Dhuha,, Desrita,, T, Siregar, Muammar, 2017, Kondisi Habitat dan Keragaman Nekton di Hulu Daerah Aliran Sungai Wampu, Kabupaten Langkat, Provinsi Sumatera Utara, Jurnal Ilmu-Ilmu Perairan, Pesisir dan Perikanan, 6 (2): 90-99

Roberts, TR, 1989, The Fresh Water Fishes of Western Borneo (Kalimantan Barat, Indonesia), Calif, Acad, Sci, Mem

Safitri, N, 2015, Pengaruh Tingkat Intensitas Cahaya terhadap Petumbuhan dan Sintasan Benih Ikan Gabus Channa Striata, Skripsi, Fakultas Perikanan dan Kelautan, Institut Pertanian Bogor

Said, DS dan Mayasari N, 2010, Pertumbuhan dan Pola Reproduksi Ikan Bada Rasbora Argyrotaenia pada Rasio Kelamin yang Berbeda, Limnotek 17(2) : 201 -209

Salmin, 2005, Oksigen Terlarut dan Kebutuhan Oksigen Biologi (BOD) Sebagai Salah Satu Indikator Untuk Menentukan Kualitas Perairan, Jurnal Institut Pertanian Bogor

Sihombing, ME, 2012, Pengaruh Intensitas Cahaya Lampu Bawah Air dengan Senter Light Emitting Diode pada Raksi Fototaksis Ikan di Prairan Kepulauan Seribu, Skripsi, Bogor (ID): Institut Pertanian Bogor

Welcomme, R, L, 2001, Inland Fisheries, Ecology, and Management, London:Fishing News Book, A division of Blackwell Science, $358 \mathrm{~h}$

Zakeyudin MS,, Mat Isa M,, Md Rawi CS,, Amir,, Md Shah S, Ahmad AH, 2012, Assessment of Suitability of Kerian River Tributaries Using Length-weight Relationship and Relative Condition Factor of Six Freshwater Fish Species, Journal of Environment and Earth Science 2 (3) : 52-60 